\section{Borassus aethiopum, A Potential Medicinal Source of Antioxidants, Anti-Inflammatory and Antimicrobial Agents}

\section{Abstract}

Background: Borassus aethiopum Mart (Family Arecaceae), commonly known as the African Fan Palm, is a tropical plant species found widely across Africa, and used globally for both medicinal and non-medicinal purposes. In this study, the anti-oxidant, anti-microbial and anti-inflammatory activities of an ethanolic extract of the fruit of Borassus aethiopum was investigated.

Methods: The Carrageenan induced foot edema model in chicks was used to investigate the anti-inflammatory activity of an ethanolic extract of the seed endocarp cotyledon. For the anti-oxidant activity determination, three assays were employed; namely, the total anti-oxidant capacity assay, the 2, 2-diphenyl1-picrylhydrazyl (DPPH) scavenging assay and the Folin-Ciocalteau's assay for total phenols. For the anti-microbial activity, the agar diffusion method was used. Phytochemical analysis to determine the types of secondary metabolites present was also conducted on the plant extract.

Results: The phytochemical screening showed the presence of alkaloid, tannins, saponins, steroids, carbohydrates triterpenoids and phenols. A dose dependent reduction in edema was observed when the extract was compared with Diclofenac and Dexamethasone. The extract had an $\mathrm{EC}_{50}$ of $13.49 \mu \mathrm{g} / \mathrm{ml} \mathrm{DPPH}$ scavenging activity, which is excellent when compared to the reference ascorbic acid of 140.00 $\mu \mathrm{g} / \mathrm{ml}$. Thus the extract was about 10 times more potent than the ascorbic acid.

Conclusion: The anti-microbial assay revealed activity against the gram positive bacteria Staphylococcus aureus and Bacillus subtilis. The results obtained showed that Borassus aethiopum has anti-inflammatory and significant anti-oxidant properties, which are dose and concentration dependent respectively.

Keywords: Borassus aethiopum; Anti-inflammatory; Anti-oxidant; Anti-microbial

Received: September 23, 2015, Accepted: September 29, 2015, Published: October 15, 2015
Joseph Sarkodie A', Sylvia Squire $A^{6}$, Irene Kretchy $A^{2}$, Emelia Bekoe $\mathrm{O}^{3}$, Charles Domozoro YF6, Kurukulasuriya Ahiagbe $\mathrm{MJ}^{6}$, Emmanuella Adjei ${ }^{1}$, Dominic Edoh A?, Isaac Amponsah $\mathrm{K}^{5}$, Maxwell Sakyiama5, Vida Lamptey $\mathrm{K}^{6}$, Seigfried Affedzi-Obresi ${ }^{6}$, John Duncan L ${ }^{6}$, Philip Debrah ${ }^{3}$,

\section{Benoit N'guessan $B^{4}$ and}

\section{Alexander Nyarko $\mathrm{K}^{4}$}

1 Department of Pharmacognosy and Herbal Medicine, School of Pharmacy, College of Health Sciences, University of Ghana Accra, Ghana

2 Department of Pharmacy Practice and Clinical Pharmacy, School of Pharmacy, College of Health Sciences, University of Ghana, Legon, Ghana

3 Department of Pharmaceutics and Microbiology, School of Pharmacy, College of Health Sciences, University of Ghana, Legon, Ghana

4 Department of Pharmacology and Toxicology, School of Pharmacy, College of Health Sciences, University of Ghana, Legon, Accra, Ghana

5 Department of Pharmacognosy, Faculty of Pharmacy and Pharmaceutical

Sciences, Kwame Nkrumah University of Science and Technology, Kumasi, Ghana

6 Animal Research Institute, Council for Scientific and Industrial Research

7 Department of Phytochemistry, Centre for Plant Medicine Research, MampongAkwapim, Ghana 
Department of Pharmacognosy and Herbal Medicine, School of Pharmacy, University of Ghana, Ghana

Citation: Sarkodie AJ, Squire AS, Kretchy Al, et al. Borassus aethiopum, A Potential Medicinal Source of Antioxidants, Anti-Inflammatory and Antimicrobial Agents. Herb Med. 2015, 2:1.

\section{Background}

Inflammation is a manifestation of the body's mechanism of defending itself against injury and the entry of foreign materials and micro-organisms which is characterized by swelling, pain, heat, loss of function, and redness of the dermis [1]. Inflammation is beneficial but can be harmful when there is excessive production of reactive oxygen species (ROS) as a result of imbalance with biological antioxidants, which can lead to oxidative stress [2]. Borassus aethiopum Mart (Arecaceae) is a tropical plant species that grows widely across Africa (Figure 1A). Ornamentally, the leaves of the palm have served the basketry and mat industries. The trunk has been used in constructing bridges, and telegraphic poles due to its tough and termite resistant nature [3]. The roots, leaves, flowers and fruits are used for multiple purposes such as nutrition agents, treatment for sexually transmitted diseases (e.g., beign herpes), cutaneous fungal infections, and viral infections particularly measles [4]. The antipyretic activities of this plant have also been reported [5]. The flowers are used to treat impetigo, whereas the roots are used for asthma treatment [3]. The fruit contains sugars, provitamin $A$ and vitamin C [6]. The sap is usually boiled immediately after extraction to make sugar or fermented to produce an alcoholic beverage. Also, the mature hard nuts are grounded and used in porridge [7] yet; anecdotal evidence suggests its folkloric antiinflammation activity [4]. Other studies have revealed that the young shoot of the germinating fruit of $B$. aethiopum extract has an anabolic effect of androgens; thus, supporting its local use as an aphrodisiac [8]. Further, the methanolic seed coat of Borassus flabellifer has been shown to possess free radical scavenging action and its leaves have an effective anthelmintic activity against Indian adult earth worms $[9,10]$. Pectin has been
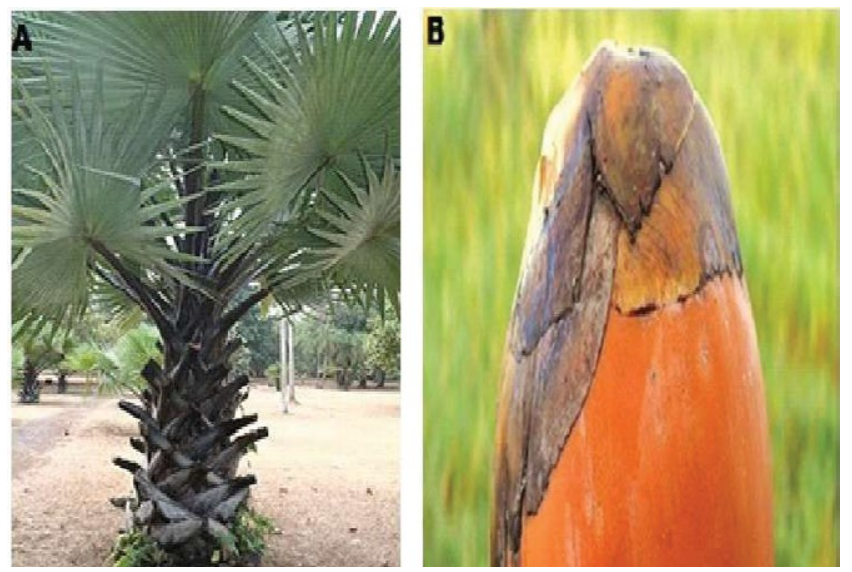

Figure 1 Borassus aethiopium tree (A) and fruit (B). extracted from the ripe fruit of $B$. aethiopum [11]. Again starch isolated from the germinating nuts of $B$. aethiopum has been found to have low water binding capacity and limiting swelling and solubility values [12]. Chemically prepared activated carbon derived from $B$. aethiopum flower has been found to be used as adsorbent [13]. Deionized extract of $B$. aethiopum shells have been reported to be used as a precursor for activated carbon preparation [14]. The anti-fungal and anti-bacterial activities of a 50:50 dichloromethane-methanol extract of the male inflorescences of $B$. aethiopum in mice have been found [15]. However, these studies did not investigate the ethanolic extract of endocarp portion of $B$. aethiopum as potential medicinal source of antioxidants, anti-inflammatory and antimicrobial agents in Ghana, though the edible flesh seed of Borassus aethiopum is used by inhabitants of several communities in Ghana to treat diarrhea and muscle tremor in indigenous poultry species including Guinea fowls (Numida meleagris) (unpublished). It would therefore be of interest to delve into its scientific potential as an anti-inflammatory agent, as well as its anti-oxidant and antimicrobial properties.

\section{Materials and Methods}

\section{Plant collection, authentication and extraction}

The fruit of Borassus aethiopum (Figure 1B) was collected from Tsakoidzi in the Volta Region of Ghana. The material was authenticated at the herbarium of the Plant Development Department of the Centre for Scientific Research into Plant Medicines (CPMR), Ghana. The plant sample was given a voucher specimen number of DPHM/003/04/15. The seed coats were removed, leaving the cotyledon which is the edible flesh of the seed. It was then air-dried for two weeks, after which it was milled into coarse powder and kept in the lab until it was ready for use. Five hundred grams of the powdered plant material was placed in a stoppered/tightly closed container containing 1 liter of $70 \%$ ethanol. The mixture was cold macerated at room temperature for a period of two days with frequent agitation until the soluble matter was dissolved. The solution was then filtered through Whatmann number 10 filter paper. The $70 \%$ ethanolic extract was concentrated in vacuo at $40^{\circ} \mathrm{C}$, and further dried in an oven to give an extract yield of $1.01 \% \mathrm{w} /{ }_{w}$ (weight by weight) per dried plant material.

\section{Phytochemical analysis}

Phytochemical analysis was carried out on the dried $70 \%$ ethanol extract of Borassus aethiopum according to the method of [16]. To test for the presence of saponins for instance, $10 \mathrm{mg}$ of the extract was added to $20 \mathrm{ml}$ of water and was shaken. The presence of a stable persistent froth indicated the presence of saponins. 
The standard protocol was followed to test for alkoids, tannins, glycosides, flavonoids, triterpenoids, anthracene glycosides, phytosteroids and phenols.

\section{Anti-inflammatory studies}

Experimental animals: One day post-hatch cockerels (Gallus gallus) were obtained from Akate Farms in Kumasi, Ghana and were housed in stainless steel cages $\left(34 \times 57 \times 40 \mathrm{~cm}^{3}\right)$ at a population density of 10 chicks per cage. Feed (Chick Mach, GAFCO) and water were available ad libitum. Overhead incandescent illumination was maintained on a 12 hour lightdark cycle. The room was maintained at a temperature of $29^{\circ} \mathrm{C}$ and relative humidity of $60-70 \%$. Daily maintenance of the cages was conducted during the first quarter of the light cycle. All procedures used in this study were in accordance with the National Institute of Health Guidelines for the Care and Use of Laboratory Animals [17] and use of laboratory animals and was approved by the Department of Pharmacology Ethics Committee, School of Pharmacy, University of Ghana, Legon, Ghana. The chicks were used for the experiment at seven days of age. The sample size for the various groups was five.

Anti-inflammatory assay of extract: The anti-inflammatory activity was investigated using the carrageenan induced foot edema model in 7-day old chicks. This focused on the curative effect of the extract during inflammation. The initial foot volume of the chicks was measured using Vernier calliper before the injection of the $2 \% \mathrm{w} /{ }_{v}$ (weight by volume) carrageenan. One hour after injection, the foot volumes of the chicks were measured again. After treating them with the various extracts, the foot volumes of the chicks were measured again using Vernier calliper at an hourly interval for 5 hours, as described by [18]. The edema component of inflammation was the difference between the initial foot volume and the foot volume after the injection of the $2 \%$ carrageenan at the various time intervals. The extracts were given to the chicks orally at 30,100 , and $300 \mathrm{mg} / \mathrm{kg}$ body weight. The standard or reference drugs, dexamethasone $(0.3,1$, and $3 \mathrm{mg} / \mathrm{kg}$ ) and Diclofenac (10, 30 and $100 \mathrm{mg} / \mathrm{kg}$ ) were also given orally. The control animals received only distilled water. The percentage inhibition of foot edema for each treatment was then calculated using the formula

$\%$ inhibition of edema $=\frac{[\text { AUC control }- \text { AUC treatment }]}{[\text { AUC control }]} \times 100$

\section{AUC-Area under curve}

\section{Anti-oxidant studies}

Total antioxidant capacity assay: This assay is based on the reduction of molybdenum, $\mathrm{Mo}^{+6}$ to $\mathrm{Mo}^{+5}$, by the plant extract, followed by the formation of green phosphate-molybdate $\left(\mathrm{Mo}^{+5}\right)$ complex at an acidic $\mathrm{pH}$ [19]. Five concentrations of vitamin $C(100,50,25,12.5,6.25 \mu \mathrm{g} / \mathrm{ml})$ was used to construct a calibration curve. A $1 \mathrm{ml}$ of the plant extract (500, 250, 125 and $62.5 \mu \mathrm{g} / \mathrm{ml}$ ) was added to test tubes containing $3 \mathrm{ml}$ of the reagent solution $(0.6 \mathrm{M}$ sulphuric acid, $28 \mathrm{~mm}$ disodium phosphate and $4 \mathrm{~mm}$ ammonium molybdate) and incubated at $95^{\circ} \mathrm{C}$ for 90 minutes. The absorbance was determined at $\lambda$ $695 \mathrm{~nm}$ in a spectrophotometer after the mixture was allowed to cool to room temperature. A blank solution was prepared by adding every other solution except the standard drug or extract. The antioxidant capacity was expressed as milligram $(\mathrm{mg})$ of vitamin C equivalent (AAE) per gram of extract.

\section{2,2-diphenyl-1-picrylhydrazyl (DPPH) scavenging activity:}

The free radical scavenging activity was determined as described by [20]. A $1 \mathrm{ml}$ quantity of the plant extract (500, 250,125 and $62.5 \mu \mathrm{g} / \mathrm{ml}$ ) was added to $3 \mathrm{ml}$ methanol solution of DPPH in a test tube and incubated at $25^{\circ} \mathrm{C}$ for 30 minutes. The absorbance of the mixture was determined at $\lambda 517 \mathrm{~nm}$ in a spectrophotometer. A solution of $1 \mathrm{ml}$ methanol and 3 $\mathrm{ml}$ of DPPH was made and incubated at $25^{\circ} \mathrm{C}$ for 30 minutes and used as control. Ascorbic acid (100, 50, 25, 12.5 and 6.25 $\mu \mathrm{g} / \mathrm{ml}$ was used as a standard free radical scavenger. Results were expressed as percentages of blank. The $\mathrm{EC}_{50}$ which is the concentration required to scavenge $50 \%$ of the DPPH molecules was calculated. Each test was carried out in triplicates. The \% DPPH scavenging effect (\% of control) of the antioxidant was calculated as follows;

\% DPPH scavenging effects $=(A c-A t) / A c \times 100(2)$

Where, $A c=A b s o r b a n c e$ of the control, At=Absorbance of the test drug/ extract. Concentrations responsible for $50 \%$ of the maximal effect in the DPPH assay $\left(\mathrm{EC}_{50}\right)$ for each drug/extract was determined.

\section{Folin-Ciocalteau's assay for total phenols}

The soluble phenol present in the extract $(62.5-500 \mu \mathrm{g} / \mathrm{ml})$ was quantitatively determined by the Folin-Ciocalteau's assay for total phenols [21]. Tannic acid $(6.25-100 \mu \mathrm{g} / \mathrm{ml})$ was used as the reference drug. A $1 \mathrm{ml}$ of the test drug was added to $1 \mathrm{ml}$ of Folin-Ciocalteau's reagent (diluted five times with distilled water). The content of the test tube was mixed and allowed to stand for fifteen minutes at $25^{\circ} \mathrm{C}$ in an oven. An amount of $1 \mathrm{ml}$ of $2 \%$ sodium bicarbonate solution was added to the mixture. The reaction mixture was further incubated at $25^{\circ} \mathrm{C}$ for 30 minutes. The absorbance of the mixture was then determined at $\lambda 760$ $\mathrm{nm}$ using a UV-VIS spectrophotometer. A $1 \mathrm{ml}$ of distilled water was added to one milliliter Folin-Ciocalteau's phenol reagent and the mixture processed similarly as the test drugs and used as the blank. All measurements were done in triplicates. Data obtained for the tannic acid was analyzed as linear regression of the absorbance against concentration from which the tannic acid equivalents were obtained. The data obtained were expressed graphically as column graphs of concentration against the tannic acid equivalent (Total Phenol Content) using the Graph Pad Prism for Windows version 5 (Graph Pad software, San Diego, CA, USA).

\section{Anti-microbial assay}

Agar diffusion method: The minimum inhibitory concentration (MIC) was determined using the Agar Diffusion method. A solution of the plant extract $0.1 \% \mathrm{w} / \mathrm{v}$ was prepared with $4 \%$ using Tween 60 and diluted to $0.001 \%, 0.002 \%, 0.004 \%$ and $0.008 \% \mathrm{w} / \mathrm{v}$. A $20 \mathrm{ml}$ of stabilizer nutrient agar was seeded with 
$100 \mu \mathrm{l}$ of a 24 hour broth cultured of Escherichia coli NCTC1351 and aseptically transferred into a sterile petri dish. The procedure was repeated using Staphylococcus aureus NCTC6571, clinical isolates of Bacillus subtilis and Pseudomonas aeruginosa. The agar was allowed to set. Using a $10 \mathrm{~mm}$ diameter cork borer, four holes were made in the agar with reasonable spacing. Each of the holes was filled with $0.1 \mathrm{ml}$ of different concentration of the plant extract. The plates were pre-incubated for an hour and incubated at $37^{\circ} \mathrm{C}$ for 24 hours. The reference drug, gentamicin $10 \mu \mathrm{g} / \mathrm{ml}$ was used as positive control.

\section{Results}

\section{Results of phytochemical analysis}

The phytochemical constituents found to be present in the extract were alkaloids, tannins, saponins, triterpenoids and phenols. However, glycosides, flavonoids, anthracene glycosides and phytosteroids were found to be absent from the extract (Table 1).

\section{Anti-inflammatory activity}

The carrageenan-induced foot edema in chicks' model was used to assess the anti-inflammatory activity of the Borassus aethiopium extract. The extracts were given per os to the chicks at $30 \mathrm{mg} / \mathrm{kg}, 100 \mathrm{mg} / \mathrm{kg}$ and $300 \mathrm{mg} / \mathrm{kg}, 1$ hour after induction of edema with $2 \% \mathrm{w} /$ carrageenan. Diclofenac $(10-100 \mathrm{mg} / \mathrm{kg}$, per os) and dexamethasone (0.1-3 $\mathrm{mg} / \mathrm{kg}$, oral administration) were used as reference drugs (Table 2). Induction of acute inflammation in control chicks resulted in a prominent increase in paw thickness, which began 1 hour after intraplantar injection of carrageenan and reached a peak of inflammation after 2 hours and slowly declined for the next 3 hours. The extract, caused significant dose-dependent inhibition of the carrageenaninduced inflammation (Figure 5 ) in the seven day old chicks $(P<0.001)$, the effect of which began 2 hours after carrageenan injection. Diclofenac and dexamethasone showed significant effect (Figure 6 ) on the time course curve $(P<0.001)$, and dose

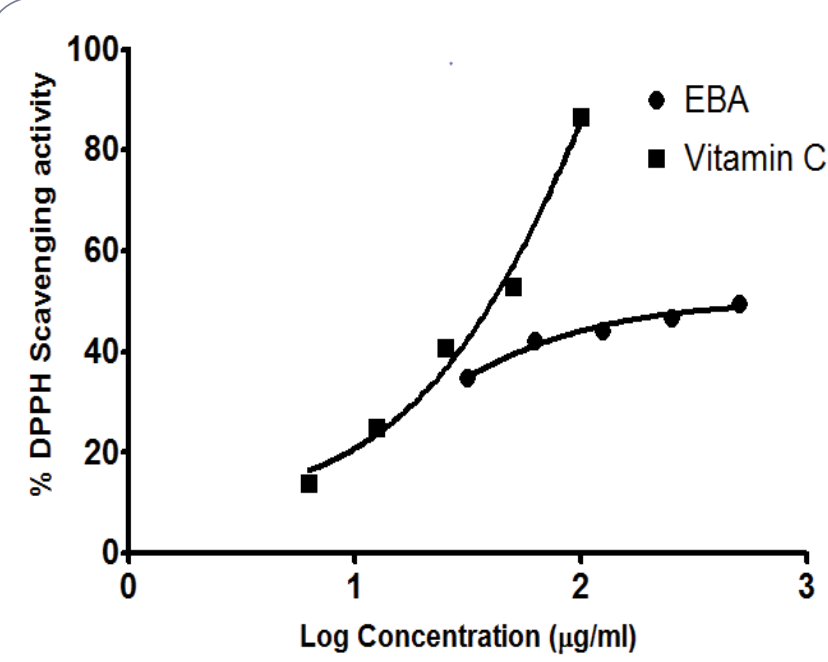

Figure 2 Percentage DPPH scavenging activity against Log concentration of ethanol extract of Borassus aethiopum seed (EBA) and Vitamin $\mathrm{C}$ with $\mathrm{EC}_{50}$ values of 13.49 and $140.00 \mu \mathrm{g} / \mathrm{ml}$ respectively. dependently reduced the total edema induced by intraplantar injection of carrageenan (Figure 7). Diclofenac showed the highest anti-inflammatory activity, followed by the extract of $B$. aethiopum, then dexamethasone (Table $\mathbf{3}$ ).

\section{Results of anti-oxidant assays}

DPPH radical scavenging activity: In this assay, both the extract and reference ascorbic acid showed a concentration-dependent scavenging effect. The DPPH scavenging activity of the extract showed a concentration dependent radical scavenging activity with $\mathrm{EC}_{50}$ value of $13.49 \mu \mathrm{g} / \mathrm{ml}$ (Figure 2).

Total anti-oxidant capacity: In this assay, the standard drug used was vitamin $C$ and a calibration curve was plotted as shown (Figure 3a). The anti-oxidant activity was expressed as milligram of ascorbic acid equivalent per gram of extract. The extract showed a total antioxidant activity of $329.4 \mathrm{mg}$ of vitamin C equivalent per gram. The extract gave a concentration-dependent anti-oxidant activity (Figure $3 \mathbf{b}$ ).

Total phenol content: In this assay, tannic acid was used as the standard anti-oxidant drug to develop the calibration curve (Figure 4a). The total phenol content was expressed as mg of tannic acid equivalence per gram of extract. The extract showed a concentration-dependent total phenolic content. The phenol content was $73.65 \mathrm{mg}$ of tannic acid equivalent per gram of the extract (Figure $\mathbf{4 b}$ ).

\section{Anti-microbial results}

The extract showed limited anti-bacterial activity against $S$. aureus, B. subtilis, E. coli and $P$. aeruginosa (Table 4).

\section{Discussion}

This work aimed at investigating the in vivo anti-inflammatory and in vitro anti-oxidant and antimicrobial properties of the ethanolic extract of the edible portion of the seed (endosperm) of $B$. aethiopum. The anti-inflammatory activity was targeted on the curative effect of the extract during inflammation. The carrageenan induced edema is mediated by multiple processes involving the release of inflammatory mediators. Carrageenan induced edema is a biphasic event, the first phase being attributed to the release of histamine and serotonin. This occurs during the first hour of injection of carrageenan, whereas the second phase is due to the release of lysosomes, prostaglandins and proteases, which occur after an hour [22]. A significant
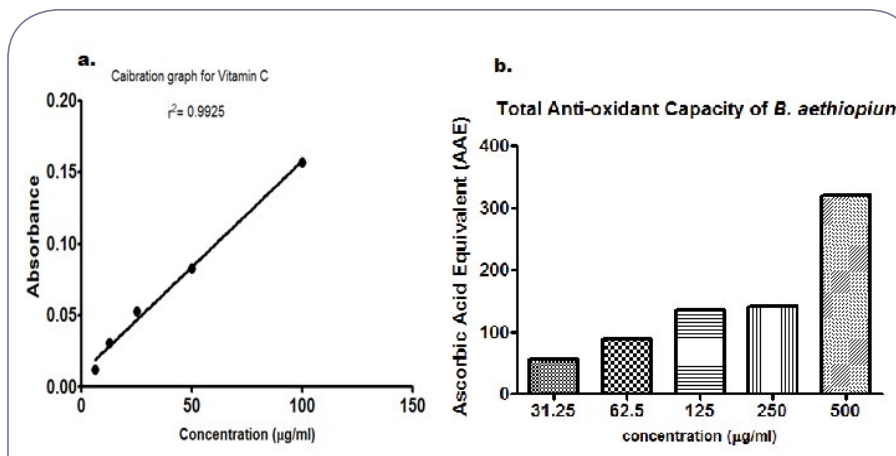

Figure 3 a. Calibration curve of Vitamin C; b. The total antioxidant capacity of the extract. 
calibration curve for tannic acid

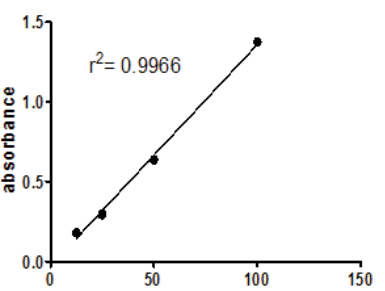

concentration $(\mu \mathrm{g} / \mathrm{ml})$ b.

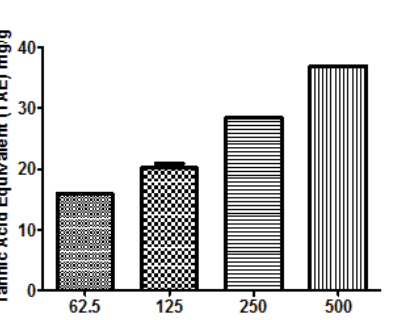

concentration $(\mu \mathrm{g} / \mathrm{ml})$

Figure 4 a. Calibration curve of tannic acid; b. and the total phenolic content of $B$. aethiopum.
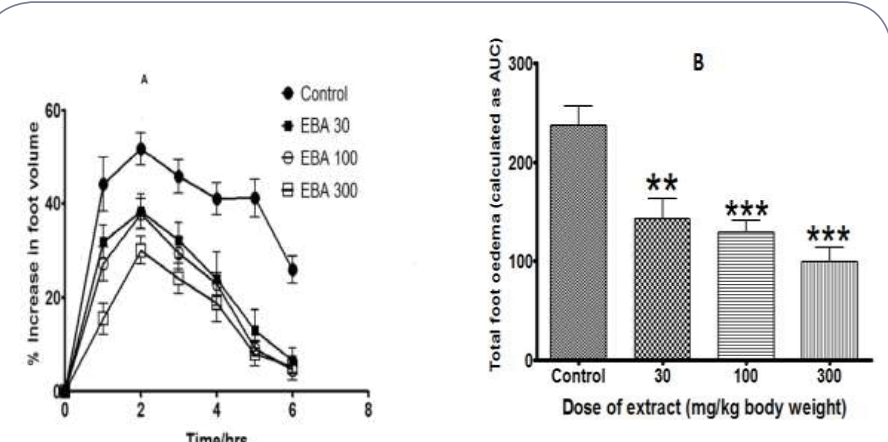

Figure 5 Effect of EBA $(30-300 \mathrm{mg} / \mathrm{kg})$ on time course of edema. (A). The total edema response, calculated as AUC's, for 6 hours, in carrageenan induced paw edema in chicks (B). Values are means \pm S.E.M $(n=5), * * * p<0.001$, $* * p<0.01$. ${ }^{*} \mathrm{p}<0.05$ compared to control group (Oneway ANOVA followed by Newman-Keul's post hoc test).
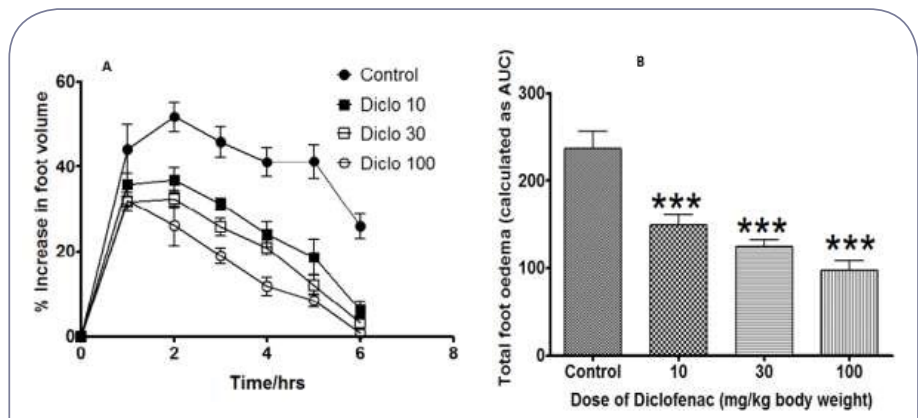

Figure 6 Effect of Diclofenac (10-100 mg/kg) on time course curve. (A). the total oedema response, calculated as AUC's, for $6 \mathrm{~h}$, in carrageenan induced paw oedema in chicks (B). Values are means \pm S.E.M $(n=5), * * * p<0.001$, ${ }^{*} p<0.01$. ${ }^{*} \mathrm{p}<0.05$ compared to control group (Oneway ANOVA followed by Newman-Keul's post hoc test).

$(p<0.01)$ anti-inflammatory effect was produced by the maximum concentration of the extract used $(300 \mathrm{mg} / \mathrm{kg})$. This significant inhibition was seen in the second hour of inflammation, indicating that the extract produced its anti-inflammatory effect probably by inhibiting the release prostaglandins, stabilizing the lysosomal membrane or by inhibiting the release of lysosomal enzyme [23]. Results showed that the extract produced a dose dependent anti-inflammatory effect. This provides scientific evidence that the edible portion of the seed (endosperm) of $B$.
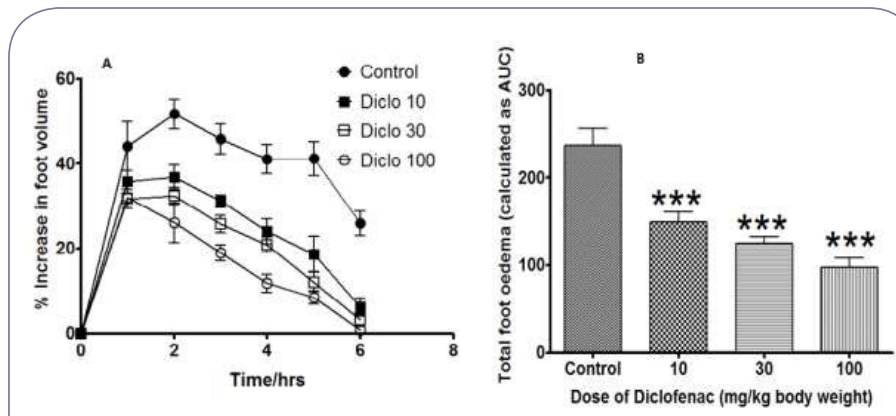

Figure 7 Effect of Dexamethasone $(0.3-3 \mathrm{mg} / \mathrm{kg})$ on time course curve. (A) The total edema response calculated as AUC's, for $6 \mathrm{~h}$ in carrageenan induced paw edema in chicks (B). Values are means \pm S.E.M $(n=5) * * * p<0.001$, $* * p<0.01$. ${ }^{*} \mathrm{p}<0.05$ compared to control group (Oneway ANOVA followed by Newman-Keul's post hoc test).

Table 1 Phytochemical constituents in the ethanol extract of Borassus aethiopum (EBA).

\begin{tabular}{|c|c|}
\hline Phytochemical Constituent & EBA \\
\hline Alkaloids & + \\
\hline Tannin & + \\
\hline Saponins & - \\
\hline Glycoside & - \\
\hline Flavonoids & + \\
\hline Triterpernoids & - \\
\hline Anthracene Glycoside & - \\
\hline Phytosteroids & + \\
\hline Phenols & \\
\hline
\end{tabular}

Table 2 Percentage inhibition of edema of the various drugs and their respective doses.

\begin{tabular}{|c|c|c|}
\hline Drug & DOSE $(\mathbf{m g} / \mathbf{K g})$ & Inhibition of edema (\%) \\
\hline EBA & 300 & 58.02 \\
\hline Diclofenac & 100 & 58.68 \\
\hline Dexamethasone & 3 & 57.07 \\
\hline
\end{tabular}

EBA: Ethanol extract of B. aethiopum

Table 3 Anti-inflammatory activity of extract and standard drugs.

\begin{tabular}{|c|c|}
\hline Drug & ED50 $(\mathbf{m g} / \mathbf{k g})$ \\
\hline EBA & $186.2 \pm 0.133$ \\
\hline Diclofenac & $30.16 \pm 0.266$ \\
\hline Dexamethasone & $3.265 \pm 0.111$ \\
\hline
\end{tabular}

aethiopum has anti-inflammatory properties. This may explain the ethno-veterinary use of $B$. aethiopum in treatment of edema and tremor in muscles in Guinea fowls during preliminary stages of this study (unpublished). Thus, there is the need to further investigate the bioactive constituents that may be responsible for the effect on inflammation. Inflammation is implicated in a number of disease conditions such as arthritis, inflammatory bowel disease, cardiovascular disease, metabolic syndrome, diabetes, obesity, autoimmune disease, dementia, osteoporosis, cancer and asthma [24]. The plant extract showed the presence of triterpenoids, saponins, tannins, phenols and alkaloids. Other researchers have shown that different phytochemicals possess a wide range of activities, which may help in the protection 
Table 4 Zones of inhibition of the plant extract and standard drug.

\begin{tabular}{|c|c|c|c|c|}
\hline Concentration of extract $(\% \mathrm{w} / \mathrm{v})$ & \multicolumn{4}{|c|}{ Average Zones of Inhibition (mm) } \\
\hline 0.008 & S. aureus & E. coli & P. aureginosa & B. subtilis \\
\hline 0.004 & $12.0 \pm 0.03$ & $18.5 \pm 0.02$ & $14.9 \pm 0.03$ & $14.4 \pm 0.02$ \\
\hline 0.002 & $11.3 \pm 0.32$ & $14.5 \pm 0.01$ & $14.0 \pm 0.03$ & $12.0 \pm 0.04$ \\
\hline 0.001 & $11.0 \pm 0.00$ & $13.5 \pm 0.01$ & $12.9 \pm 0.03$ & $11.0 \pm 0.03$ \\
\hline Gentamycin $10 \mu \mathrm{gg} / \mathrm{ml}$ & $10.0 \pm 0.00$ & $10.9 \pm 0.14$ & $12.0 \pm 0.01$ & $10.1 \pm 0.06$ \\
\hline
\end{tabular}

against inflammatory diseases [25,26]. Glycosides, saponins, flavonoids, tannins, alkaloids and triterpenoids have been reported to possess anti-inflammatory activities and therefore could be responsible for the anti-inflammatory activity of the extract. Chronic inflammations can lead to oxidative stress [27]. Therefore the anti-oxidant activity of the extract was investigated using the DPPH radical scavenging activity and the total antioxidant capacity assays. In the DPPH scavenging activity the extract showed a concentration dependent radical scavenging activity with $\mathrm{EC}_{50}$ value of $13.49 \mu \mathrm{g} / \mathrm{ml}$, whereas that of ascorbic acid, was $140.0 \mu \mathrm{g} / \mathrm{ml}$. Thus the extract was about 10 times more potent than that of ascorbic acid. In an inflammatory process, there is excessive production of ROS as a result of imbalance of biological antioxidants which can lead to oxidative stress. Also reactive oxygen metabolites from phagocytic leukocytes may invade body tissues causing injury to them [2]. As a matter of fact plants that contain compounds that have the ability to scavenge these reactive oxygen species play significant role in treating and managing inflammation [23].

The extract showed a total antioxidant activity of $329.4 \mathrm{mg}$ of Vitamin $C$ equivalent per gram of extract whereas the total phenol content was $73.65 \mathrm{mg}$ of tannic acid equivalent per gram. Phenolic compounds have the ability to scavenge free radicals, which makes them good anti-oxidants [27]. From the correlation between the total phenolic content and the total anti-oxidant capacity, a coefficient of 0.8270 was obtained. This value indicates that $82.70 \%$ of the anti-oxidant activity of the extract may be as a result of its phenolic content. The remaining $17.30 \%$ of its antioxidant activity can be attributed to other secondary metabolites present in the extract. It can be deduced from the results that, the anti-oxidant property of the extract might have helped in delaying and curing the inflammatory process.

The plant extract exhibited broad spectrum antibacterial activity against $B$. subtilis and S. aureus. However, at $0.008 \%$ w/v concentration of the extract, high zones of Inhibition were observed against $E$. coli and $P$. aeruginosa. Gram-negative bacteria are generally more resistant compared to the Gram-positive ones [28]. Alkaloids, saponins, phenols, tannins and triterpenoids found in the phytochemical screening may have contributed to the antimicrobial activity observed. The importance of alkaloids, saponins and tannins in various as antibiotics used in treating common pathogenic strains has been reported [29,30]. Alkaloids have been found to intercalate into cell wall and DNA of parasites, triterpenoids also cause membrane disruption whereas tannins bind to adhesions, inhibit enzyme inhibition, cause substrate deprivation, complex with cell wall, cause membrane disruption, and metal ion complexation [31]. In the process of wound formation there is a release of inflammatory cytokines and reactive oxygen species. Wounds as a matter of fact predispose one to opportunistic infections and as such antimicrobials also play a significant role in wound management. Since extract of $B$. aethiopum showed activity against $S$. aureus and $B$. subtilis (which are commonly found in infected sores and wounds), it may be useful as a wound healing agent in human and ethnoveterinary medicine.

\section{Conclusion}

The $70 \%$ ethanolic extract of the seed (endosperm) of $B$. aethiopum exhibited both dose dependent anti-inflammatory and concentration dependent anti-oxidant activities. It also possessed antimicrobial effect against both Gram-positive and Gram-negative bacteria. The prominent anti-oxidant activity of the extract may provide cytoprotection of cells against the ROS produced during inflammation. Its anti-microbial activity is also likely to reduce the extent of inflammation during infection. These results seem to justify the folkloric use of the plant material for the treatment of infections and possibly some inflammatory conditions in both humans and animals. 


\section{References}

1 Lippincott Williams, Wilkin (2009) Lippincott's illustrated reviews: Pharmacology. 4th edn. Lippincott's Williams \& Wilkins, Florida, America.

2 Hakim J (1993) Reactive oxygen species and inflammation. Soc Biol Fil 187: 286-295.

3 Mshana NR, Abbiw DK, Addae-Mensah I, Adjanouhoun E, Ahyi MRA, et al. (2000) Traditional Medicine and Pharmacopoeia. Contribution to the Revision of Ethnobotanical and Floristic Studies in Ghana

4 Sakande J, Nikiéma A, Kabré E, Lompo M, Nikiema JB, et al. (2012) In vitro assay of potential antifungal and antibacterial activities of extracts of Borassus aethiopum Mart. Intern J of Nigerian Soc 24: $48-51$.

5 Sakande J, Nacoulma OG, Nikiema JB, Lompo M, Bassene E, et al. (2014) Study of the antipyretic effect of Borassus aethiopum male inflorescences extracts. Med d'Afrique Noire 51: 280-282.

6 Ahmed A, Djibrilla A, Clergé T, Clément (2010) Physico-chemical properties of palmyra palm (Borassus aethiopum Mart.) fruits from Northern Cameroon. African J of Food Sci. 4: 115-119.

7 Bokhari M, Ahmed CHMS (1978) Food Plants in Borno State, Maidugun, Nigeria. Gulamari Publishers.

8 Akinniyi JA, Waziri M, Usman HS (2010) Assessment of the Anabolic Effect of Androgens of the Edible portion of the shoot of Giginya plant (Borassus aethiopum). J Sci Res 2: 362-368.

9 Sastry NY, Padmaja IJ, Rao RP, Kirani KRLS, Kaladhar D, et al. (2012) In vitro dose dependent study on anti-human pathogenic bacterial and free radical scavenging activities of methanolic seed coat extract of Borassus flabellifer. L Asian J Pharm Clin Res 5: 83-86.

10 Jamkhande PG, Suryawanshi VA, Wattamwar AS, Barde SR (2014) In vitro anthelmintic efficacy of Borassus flabellifer Linn (Palmae) against Pheretima posthuma. Asian Pac J Trop Dis 4: 199-203.

11 Assoi S, Konan K, Walker LT, Holser R, Agbo GN, et al. (2014) Functionality and yield of pectin extracted from Palmyra palm (Borassus aethiopum Mart) fruit. Food Sci and Tech 58: 214-221.

12 Barminasa JT, Onen Al, Williams ET, Zaruwa MZ, Mamuru SA, et al. (2008) Studies on functional properties of borassus starch from fresh germinating nuts of giginya (Borassus aethiopum) palm. Food Hydrocolloids 22: 298-304

13 Nethajia S, Sivasamya A, Thennarasua G, Saravanan (2010) Adsorption of Malachite Green dye onto activated carbon derived from Borassus aethiopum flower biomass. J of Hazardous Materials 181: $271-280$

14 Zaharaddeen NG, Afidah AR, Saadatu AH (2014) Potential of Borassus aethiopum shells as precursor for activated carbon preparation by physico-chemical activation; optimization, equilibrium and kinetic studies. J of Env Chem Eng 2: 1423-1433.

15 Sakande J, Kabre E, Lompo M, Pale E, Nikiema JB, et al. (2013) Antiinflammatory and Antioxidant Activities of a Fraction 11 of Male Inflorescences of Borassus aethiopum Mart (Arecaceae). American $\mathrm{J}$ of Biochem and Molecular Biol 3: 101-109.
16 Trease GE, Evans WC (1989) Pharmacognosy $13^{\text {th }}$ edition, London :176-180.

17 National Institute of Health Guidelines (1985) Department of Health Services Publication 85.

18 Joseph SM, George MC, Nair JR (2005) Effect of feeding cuttlefish liver oil on immune function, inflammatory response and platelet aggregation in rats. Curr Sci 88: 507-510.

19 Prieto P, Pineda M, Aguilar M (1999) Spectrophotometric quantification of antioxidant capacity through the formation of a phosphomolybdenum complex: specific application to the determination of vitamin E. Anal Biochem 269: 337-341.

20 Govindarajan R, Rastogi S, Vijayakumar M, Shirwaikar A, Rawat AK, et al. (2003) Studies on the antioxidant activities of Desmodium gangetium. Biol Pharm Bull 26: 1424-1427.

21 Slinkard J, Singleton VL (1977) Total phenol analysis: automation and comparison with manual methods. American. J of Enol and Vitic 28: 49-55.

22 Asongalem EA, Martins FR, Matheus ME (2005) Investigation of anti-inflammatory, lack of central analgesia and antipyretic properties of Acanthus montanus (Ness) T Anderson. J Ethnopharmacol 95: 63-68.

23 Silva GN, Martins FR, Matheus ME, Leitao SG, Fernandes PD (2005) Investigation of anti-inflammatory and anti-nociceptive activities of Lantana trifolia. J Ethnopharmacol 100: 254-259.

24 Ridker PM, Cushman M, Stampfer MJ, Tracy RP, Hennekens HC (1997) Inflammation, aspirin, and the risk of cardiovascular disease in apparently healthy men N Engl. J Med 336: 973-979.

25 Augusti KT, Cherian S(2008) Insulin sparing action of leucopelargonidin derivative isolated from Ficus bengalesis Linn. Indian J Exp Biol 33: 608-611.

26 Mir MA, Sawhney SS, Jassal MMS (2013) Qualitative and quantitative analysis of phytochemicals of Taraxacum officinale. Wudpecke.r J Pharm Pharmocol 2: 001-005.

27 Velioglu YS, Mazza G, Gao L, Oomah BD (1998) Antioxidant activity and Total Phenols in selected fruits, vegetables and grain products. J Agric Food Chem 46: 4113-4117.

28 Cos P, Vlietinck AJ, Vanden Berghe D, Maes L (2006) Anti-infective potential of natural products: how to develop a stronger in vitro 'proof-of concept'. J Ethnopharmacol 106: 290-302.

29 Kubmarawa D, Ajoku GA, Enworem NM, Okorie DA (2007) Roles of agricultural biotechnology in ensuring adequate food security in developing societies. Afr J Biotechnol 6: 1690-1696.

30 Mensah JK, Okoli RI, Ohaju-Obodo JO, Eifediyi K (2008) Aqueous extract of Telfairia occidentalis leaves reduces blood sugar and increases haematological and reproductive indices in male rats. Afr J Biotechnol 7: 2304-2309.

31 Cowan MM (1999) Plant products as antimicrobial agents. Clin Microbiol 12: 564-582. 